$1-1-2004$

\title{
The Mechanics of Indian Gaming Management Contract Approval
}

Kevin Washburn

University of New Mexico - School of Law

Follow this and additional works at: https://digitalrepository.unm.edu/law_facultyscholarship

Part of the Indian and Aboriginal Law Commons

\section{Recommended Citation}

Kevin Washburn, The Mechanics of Indian Gaming Management Contract Approval, 8 Gaming Law Review 333 (2004).

Available at: https://digitalrepository.unm.edu/law_facultyscholarship/535

This Article is brought to you for free and open access by the UNM School of Law at UNM Digital Repository. It has been accepted for inclusion in Faculty Scholarship by an authorized administrator of UNM Digital Repository. For more information, please contact amywinter@unm.edu, Isloane@salud.unm.edu,sarahrk@unm.edu.

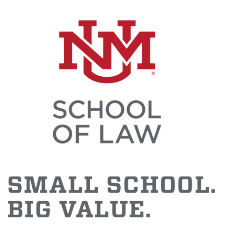

BIG VALUE. 


\title{
The Mechanics of Indian Gaming Management Contract Approval
}

\author{
KEVIN K. WASHBURN
}

$\mathbf{I}$ N THE INDiAn GAming Regulatory Act, Congress took from the Secretary of the Interior and vested with the National Indian Gaming Commission (NIGC) the responsibility to review and approve gaming management agreements between tribes and outside contractors. ${ }^{1}$ Congress intended to insure through this process, first, that Indian tribes (rather than outside parties) are the primary beneficiaries of Indian gaming and, second, that Indian gaming is shielded from organized crime and other corrupting influences. ${ }^{2}$ The Indian Gaming Regulatory Act (IGRA) and NIGC regulations set forth extensive requirements for submission and approval of gaming management contracts between Indian tribes and outside management contractors.

While the NIGC has provided occasional guidance ${ }^{3}$ and commentators have occasionally discussed some aspects of the process, ${ }^{4}$ this article is an effort to explain the nuts and bolts of the approval process in a deliberate, comprehensive and step-by-step manner. The first

Kevin K. Washburn is Associate Professor at the University of Minnesota Law School. He is a former federal prosecutor, a former trial attorney at the United States Department of Justice, and was the General Counsel at the National Indian Gaming Commission in Washington, D.C., from January 2000 to July 2002. During his tenure as General Counsel, he reviewed thirty to forty management contracts or amendments at various stages of the review process, during which time the NIGC Chairman approved eight such contracts. Only five contracts have been approved during the more than two years since his departure. This is a reflection. of the complexity of the management contract approval process. He appreciates the comments of NIGC officials Penny Coleman, Fred Stuckwisch, and Elaine Trimble on an earlier draft of this article. section explains the process from a practical viewpoint. The next section describes the substantive standards in greater depth and explains how they are practically applied by the NIGC. The final section explains how collateral agreements are relevant in this process.

\section{FUNCTIONAL OVERVIEW OF THE MANAGEMENT CONTRACT REVIEW PROCESS}

In the thirteen years that the NIGC has been in existence, the Commission has approved approximately forty-three gaming management contracts. ${ }^{5}$ The NIGC has also approved numerous contract modifications, amendments, and extensions. ${ }^{6}$ It has reviewed countless other contracts that were never approved for various reasons. The management contract re-

1 See 25 U.S.C. § $2711(\mathrm{~h})$

2 See 25 U.S.C. \$ 2702 (Declaration of Congressional Policy).

${ }^{3}$ NIGC guidance is available on the NIGC Web site at (http://www.nigc.gov).

${ }^{4}$ See, e.g., Heidi McNeil Staudenmaier, Negotiating Enforceable Tribal Gaming Management Agreements, 7 GAMING L. REv. 31 (2003).

5 Although the NIGC was authorized by statute in 1988 , the first Chairman was not appointed until 1990. A list of the approved gaming management contracts is available on the NIGC Web site, 〈http://www.nigc.gov〉. According to the list, the first NIGC management contract approval was issued on October 4, 1993, and the most recent was issued on July 19, 2004.

${ }^{6}$ Management contracts for Indian gaming are not valid unless approved by the Chairman of the NIGC. Modifications of approved gaming management contracts, such as extensions, must also be approved. See 25 C.F.R. $\$ 535.1$. 
view process at the NIGC is now routine. It proceeds roughly as follows.

The management contract review process begins when the parties submit a signed management contract for review. The time for NIGC review varies with the complexity of the management contract, the level of cooperation from the parties, and the scope of any necessary background investigations and environmental review.

Under the applicable regulations, the Chairman has only 180 days to review, and then approve or disapprove, a management contract. As a practical matter, this time limit is not a day-to-day concern for the NIGC. First, the Chairman may extend the deadline for 90 days at will as long as he notifies the parties that he is doing so. ${ }^{8}$ Second, the parties' primary means of enforcing the 180 day review requirement is an action in federal court to compel a decision by the Chairman. ${ }^{9}$ Obtaining judicial relief is likely to take a long time and might be met with hostility by Commission staff. Accordingly, parties regularly address NIGC delays with patience and cooperation. Finally, the NIGC has interpreted the law to mean that the 180-day time period does not begin to run until the NIGC receives a "complete submission." 10 Because the NIGC staff will often require the parties to modify the contract and resubmit it, the clock usually is restarted at least once after initial submission.

Though the NIGC staff works diligently to process management contracts, the NIGC staff routinely advises parties that the contract review process takes from six to eighteen months. ${ }^{11}$ In recent years, the time required for approval has sometimes stretched out more than eighteen months, largely due to environmental compliance issues, which will be discussed more below, and issues related to Indian land acquisitions. Though some contract modifications or extensions are approved in as little as six months, it is probably more prudent to estimate twelve to thirty-six months from submission to approval for an entirely new contract. While environmental review and background investigations may occasionally cause delay, a common reason for delay is lack of cooperation or sophistication by parties to management contracts and lack of responsiveness to NIGC concerns.

Submission of a management contract begins what might best be described as a negotiation process in which the NIGC asks the parties to modify or explain the contract to address issues of concern to the NIGC. Management contracts are shepherded through the NIGC review process primarily by financial analysts in the Contracts Division with guidance from attorneys in the Office of General Counsel. The review process involves substantial communication back and forth between NIGC staff and the parties, usually in a series of written communications and meetings.

In the history of the NIGC, probably no gaming management contract has ever been approved as submitted. The NIGC staff routinely raises dozens of questions and concerns and almost always requires the parties to amend the management contract, or at least provide additional clarification or justification for specific terms. Many of the changes sought by the NIGC are insignificant from the perspective of the parties. On the other hand, some of the changes may be material and, in extraordinary cases, the parties may be asked to renegotiate certain provisions, including such key terms as compensation and duration of the contract.

Frequently, the parties anticipate further negotiation and modification of the contract after it is submitted to the NIGC. The NIGC will not review a contract until it has been signed by the parties. ${ }^{12}$ Because management contracts are processed on a first come, first served basis, parties interested in obtaining financing

\footnotetext{
7 See 25 C.F.R. $\$ 533.4(a)$.

${ }^{8}$ See id.

${ }^{9}$ See 25 U.S.C. \& 2711(d).

${ }^{10} 25$ C.F.R. $\$ \S 533.4(\mathrm{a}), 533.6$.

${ }^{11}$ According to official NIGC publications, "the review is comprehensive; the length and amount of time it takes is dependent upon several factors including the completeness of each submission, the responsiveness of the parties, the degree to which the submission meets the requirements of the law, and the Commission's backlog." See Helpful Hints for Submitting a Management Contract And Obtaining the Chairman's Approval, a guidance memorandum available on the NIGC Web site at (http://www.nigc.gov).

12 See 25 C.F.R. $\$ \S 533.2,533.3(\mathrm{a})(1)$.
} 
and beginning casino construction have a strong incentive to submit contracts at the earliest possible moment to begin the NIGC process and to secure a place in the NIGC queue. ${ }^{13}$ Submission can also bring NIGC expertise to bear on the drafting process and serve to initiate other important but time-consuming NIGC processes, such as environmental review and background investigations. Thus, the typical management contract submitted to the NIGC, though signed, may be intended primarily as an initial draft with the understanding that the parties will amend the contract as needed to obtain NIGC approval and possibly to address other matters of concern between the parties. Management contracts and collateral agreements often contain blanks or even typographical errors.

Following the initial submission of a gaming management contract, the NIGC Contracts Division usually responds with a letter detailing submission deficiencies, that is, an explanation of errors in submission and a list of additional information that must be submitted before formal contract review will begin.

\section{Initial review}

Once the parties provide sufficient information for the NIGC staff to begin its review, NIGC staff in the Contracts Division will review the management contract submission and prepare an initial review memorandum setting forth potential problems and concerns and any remaining submission and content deficiencies. The memorandum prepared by NIGC staff at this stage typically will include the following information, among other things:

a. a summary of any involvement thus far by the NIGC, including the date the contract was submitted, and any actions taken since submission such as summaries of meetings between the parties;

b. a summary of the scope of the project, including general information, such as the square footage of the proposed casino, the type of gaming that may be involved, the names of the parties, and the estimated level of investment in the proposed casino (usually in the multiple millions of dollars); c. a summary of the proposed terms of the management contract;

d. a justification for extraordinary terms (if the contract calls for a term in excess of five years or a fee in excess of thirty percent of gaming revenues);

e. a summary of any collateral agreements and a description of their purposes;

f. a summary of the status of any background investigations that lists the names of persons subject to investigation;

g. a summary of the status of any environmental review;

h. a description as to the status of the determination of whether the proposed project is on Indian lands;

i. a statement as to whether there is an approved tribal gaming ordinance and the status of NIGC review of any proposed ordinance and/or the date the ordinance was approved by the NIGC;

j. for Class III management contracts, a confirmation that the tribe has an approved tribal-state compact for Class III gaming and the date of approval;

k. a lengthy list of issues and concerns that includes submission deficiencies, content deficiencies, and general concerns about the specific terms of the contract; and

1. a recommendation by NIGC staff to the General Counsel and the Director of Contracts as to the proposed course of action, which at this stage usually involves a recommendation that the NIGC staff forward a letter to the parties detailing the problems and perhaps invites the parties to have a meeting with the parties and NIGC staff to go over problem areas.

The initial review memorandum prepared by NIGC staff is usually meticulous; it will frequently include an exhaustive list of twenty to as many as eighty or more deficiencies of the

${ }^{13}$ See Helpful Hints for Submitting a Management Contract And Obtaining the Chairman's Approval," a guidance memorandum available on the NIGC Web site at 〈http://www.nigc.gov) (noting that NIGC processes management contracts on "a first-in first-out basis"). 
contract or concerns as to which the NIGC needs additional information.

While this "deficiency rate" may seem surprisingly high, the parties to a management contract tend to focus their attention at the initial drafting stages on the relationship between themselves and not on the regulatory compliance issues. In addition, management contracts involving the development of turnkey casinos often involve one or more highly complicated financial arrangements. Together with supporting documents and collateral agreements, the documents that must be reviewed often constitute hundreds of pages and may ultimately consist of several inches of paper.

The initial review memorandum, which summarizes the management agreement and addresses all the issues listed above, must be reviewed by a staff attorney in the Office of General Counsel and must be signed as "approved" by the General Counsel and the Director of the Contracts Division. This memo then serves as the basis for an initial deficiency letter to the parties, which will usually be prepared and signed by a financial analyst in the NIGC Contracts Division. The initial deficiency letter to the parties, a file copy of which must be surnamed (or initialed) by the Director of the Contracts Division and the General Counsel prior to its transmittal, identifies the numerous NIGC questions and concerns (usually setting forth the list noted in item $k$ above), seeks additional information, and will often explain modifications to the contract documents that the NIGC will require.

\section{Follow through and subsequent review}

After the parties receive the initial deficiency letter, the parties will work to gather the new information and redraft and execute a new contract, if necessary, and then submit updated documents to the NIGC. When the additional information and, if necessary, a new version of the contract is submitted by the parties, the entire process repeats, with NIGC staff reviewing the information and creating another memorandum and a new deficiency letter to the parties.

In most cases, in the second review memorandum and deficiency letter to the parties, the section listing questions and concerns is some- what shorter overall because the parties have addressed many of the NIGC staff's initial concerns. ${ }^{14}$ Nevertheless, the process often requires two to three more communications between the NIGC and the parties before the contract is ready to be approved by the NIGC staff. Often, the parties will meet with NIGC staff during this process to vent frustration, to seek NIGC guidance, or to explain issues or financial arrangements that the parties believe that the NIGC staff does not fully understand.

Because the NIGC interprets the Indian Gaming Regulatory Act as vesting with the NIGC the responsibility to insure that such contracts are "fair" to Indian tribes, 15 the NIGC sometimes inserts itself into contract negotiations in an attempt to insure that the tribe obtains the maximum advantage from the gaming project. During discussions, the NIGC staff will sometimes meet with the tribe and its attorneys apart from the management contractor to discuss particular NIGC concerns and to insure that the NIGC can obtain the tribe's frank view of the contract outside the presence of the manager. Because a contract is void absent NIGC approval, ${ }^{16}$ the NIGC has tremendous informal authority at the pre-approval stage; each of the parties is usually strongly motivated to satisfy the concerns of NIGC staff, so that they can break ground on the project, even in circumstances when they believe that the NIGC is acting beyond the scope of its authority.

\section{Approval or disapproval}

The principal decision maker at the NIGC is the Chairman. The entirety of the review process, including the discussions with the parties, is directed toward compliance with NIGC requirements so that the NIGC staff can recommend that the Chairman approve the management contract. The Chairman may disapprove

\footnotetext{
${ }^{14}$ By the time the management contract is ready for presentation to the Chairman for approval many months later, the file will usually contain several such memoranda prepared at various stages of contract review, showing the evolution of that particular management contract review.

${ }^{15}$ S' $^{\prime} 25$ U.S.C. $\$ 2711(\mathrm{e})(4)$.

${ }^{16}$ Sic 25 C.F.R. $\$ 533.7$.
} 
a management agreement for a variety of reasons related to gaming regulatory concerns that are set forth in the regulations. ${ }^{17}$

In addition, the Chairman must disapprove a management contract if he determines that a theoretical trustee for the tribe, acting with the prudence and diligence normally required of a trustee, would not approve the contract. ${ }^{18}$ This provision gives the Chairman the apparent discretionary power to second-guess business decisions by the tribe. However, because such action would not be consistent with current federal policies of treating tribes as self-governing sovereigns, disapproval on the basis of the trust responsibility is highly unusual. Though this "trust responsibility" therefore gives the NIGC staff some leverage to extract concessions from the management contractor, it does not, in practice, result in disapprovals of management contracts.

Rarely has a management contract been disapproved by the Chairman. Disapprovals are likely to occur where the parties lack sophistication to provide adequate "follow through" to complete the project approval process. ${ }^{19}$ If a contract is likely to be disapproved, members of the NIGC staff will communicate their concerns to the parties and encourage the parties to modify the contract to satisfy NIGC staff concerns or to withdraw the contract from NIGC review. Management contractors have a strong incentive to withdraw, rather than risk disapproval; disapproval by the NIGC may harm the party's reputation in the gaming industry and may have significant ramifications as to regulatory approvals with regard to other gaming jurisdictions. Moreover, although the parties have a right of appeal of a disapproval decision by the Chairman, ${ }^{20}$ parties are not likely to be willing to undergo the lengthy appeal process and the related opportunity costs, particularly in light of the unlikely result of prevailing on appeal.

\section{SUBSTANTIVE OVERVIEW OF THE MANAGEMENT CONTRACT REVIEW PROCESS}

During the course of the management contract review, the NIGC must ascertain whether the tribe has an approved Class III tribal-state gaming compact in place if the tribe is seeking to conduct Class III gaming, ${ }^{21}$ that the tribe has an approved tribal gaming ordinance; ${ }^{22}$ and that the lands upon which the facility is or will be located constitute "Indian lands" as that term is defined in IGRA and NIGC regulations. ${ }^{23}$ However, the substantive components of the management contract review process involve three main areas: legal and financial review of the contract terms, background investigations of certain individuals, and environmental compliance. This section will discuss each of these broad areas in that order.

\section{Review of the terms of the gaming management agreement}

The heart of the review process is review of the substantive management contract provisions against the specific substantive requirements set forth in the Indian Gaming Regulatory Act, 25 U.S.C. $\$ \S 2710(d)(9)$ and 2711 , and the NIGC's regulations, primarily 25 C.F.R. $\S \S$ 531 and 533. These regulations detail the requirements for submission of a management contract to the NIGC (called "submission requirements" by the NIGC staff) ${ }^{24}$ and also detail the substantive content provisions that are

17 See 25 C.F.R. $\$ 533.6(\mathrm{~b})$ and (c).

${ }^{18}$ See 25 C.F.R. $\$$ 533.6(b). Because this authority extends only to Class II contracts, the NIGC staff has maximum leverage with management contracts that include Class II gaming. Because many managers wish to keep their gaming options open, many contracts include Class II gaming, even if they are principally geared toward the more profitable Class III gaming.

19 The Chairman disapproved a management contract between First Nation Gaming, LLC, and the San Pasqual Band of Mission Indians on October 16, 2001, for failure to meet repeated requests for additional information from the Commission staff. Although the parties appealed the Chairman's disapproval to the entire Commission, the appeal was unsuccessful. The Commission ruled, under 25 C.F.R. $\$ 533.6(\mathrm{~b})(1)(\mathrm{iv})$, that the refusal to provide additional information was tantamount to a refusal to respond to questions asked by the Chairman.

20 See 25 C.F.R. $\$ 539$.

21 See 25 U.S.C. $\$ 2710(\mathrm{~d})(1)(\mathrm{C})$.

${ }^{22}$ See 25 U.S.C. $\$ \S 2710(\mathrm{~b})(1)$ and (d)(1).

${ }^{23}$ See 25 U.S.C. \$ 2703(4); 25 C.F.R. \$ 502.12.

2425 C.F.R. § 533. The NIGC checklist for new management contracts, available on the NIGC Web site, is helpful in examining these requirements. 
required ${ }^{25}$ and that are prohibited ${ }^{26}$ in management contracts (collectively referred to by the NIGC staff as "content requirements").27

To meet the submission requirements, a management contract must be submitted with, first, original signatures of authorized officials of both parties; ${ }^{28}$ second, with a representation that the contract is the entirety of the agreement among the parties; ${ }^{29}$ third, with a letter signed by the tribal chairman setting out the authority of the tribal signatory to act for the tribe, together with documents providing evidence of such authority. ${ }^{30}$ In addition, the parties must submit, fourth, a list of persons and identities subject to the background investigation requirements ${ }^{31}$ and, fifth, a three-year business plan setting forth the parties' goals, objectives, budgets, and financial plans. ${ }^{32}$ Sixth and last, the parties must submit a justification for any length of contract term in excess of the standard limit of five years or any provision for compensation in excess of the standard limit of thirty percent of net gaming revenues. ${ }^{33}$ If the submission requirements are met, the management contract must also meet numerous content requirements.

Length of term and compensation requirements. Perhaps the most noteworthy content requirement is the compensation and length of term limitations just mentioned. Under IGRA and NIGC regulations, a management contract generally may not be approved for a term exceeding five years, or for compensation in excess of thirty percent of net gaming revenues, absent extraordinary circumstances. ${ }^{34}$ The Chairman may approve a management contract term length in excess of five years (to a maximum term of seven years), or with a compensation term in excess of 30 percent of net gaming revenues (to a maximum of 40 percent), only if the Chairman is "satisfied that the capital investment required; and the income projections, for the gaming operation, require the additional time," or "the additional fee." 35

Neither IGRA nor the regulations provide further guidance as to what standards should be used to determine whether additional time or an additional fee is "required." The failure to define this term causes great difficulty and, frankly, great uncertainty in the management contract approval process. However, some rules of thumb have developed that are helpful in considering this question. First, because a management contract requires no justification if it is for no more than five years and calls for a management fee of no more than 30 percent of net gaming revenues, the NIGC generally considers the five year term and 30 percent management fee as both a safe harbor and a benchmark for comparison of any contract with terms in excess of the safe harbors. To establish a benchmark for review, the NIGC will routinely require financial projections for a hypothetical contract that would possess the 30 percent/five year safe harbor and that is otherwise ceteris paribus. The NIGC would then compare these financial projections to the projections for the contract under review. If the NIGC is able to determine that the contract under review to the tribe is more favorable to the tribe, the NIGC staff is likely to determine that the compensation term is "required" by the circumstances and recommend approval of the contract. Such circumstances may occur for example if the parties seek a length of term of six years, but call for compensation equal only to 25 percent of net gaming revenue.

In cases in which this method does not provide a definitive answer, the NIGC staff will consider a variety of ultimately uncertain variables including evidence that the project presents substantial risk to the management contractor, or that substantial revenues are not likely to exist in the early years, due to start up costs such as financing, marketing, training, and construction. Given the magnitude of costs in large projects, trying to pay all of these costs during a five-year term can impose serious burdens on a tribe, with the result that the tribe

\footnotetext{
2525 C.F.R. $\$ 531.1$.

2625 C.F.R. $\$ 531.2$.

2725 C.F.R. $\$ \S 533.1(\mathrm{~h})$ and (i).

${ }^{28}$ See 25 C.F.R. \$ 533.3(a)(1).

${ }^{29} \mathrm{See} 25$ C.F.R. § 533.3(a)(2).

${ }^{30}$ See 25 C.F.R. $\$ 533.3(\mathrm{~b})$ and (c).

${ }^{31}$ See 25 C.F.R. $\$ 533.3(\mathrm{~d})$. For greater detail, see also 25 C.F.R. § 537.1(b).

32 See 25 C.F.R. \$ 533.3(e).

33 See 25 C.F.R. $\$ \S 533.3(\mathrm{f}), 531(\mathrm{f})$.

${ }^{34}$ See 25 U.S.C. $\$ 2711$ (b)(5) and (c)(2); 25 C.F.R. $\$ 531.1(\mathrm{~h})$ and (i).

35 Id.
} 
sees little or no revenue in the early years of a management contract. The tribe may very well wish to receive more revenue during the early years when the costs of repaying construction and startup costs are far greater as a percentage of overall revenue. If a contract calls for the term to be lengthened so that the tribe receives greater benefit in the early years, the NIGC staff may look more favorably on the excess terms, particularly if the agreement offers the tribe substantially greater revenue in the short term. Because many recent projects have involved construction costs in excess of $\$ 100$ million, it is not unusual for parties to submit, and the NIGC to approve, management contracts with terms in excess of the safe harbors of five years $/ 30$ percent.

If the NIGC fails to find the excess terms justified, however, then NIGC staff generally will encourage the parties to redraft the contract. One imperfect manner in which parties can meet the term requirement is to redraft a contract for a five-year term with an option for a two-year extension with consent of both parties.

Other management contract "content" requirements. In addition to the compensation and length of term requirements, IGRA and/or NIGC regulations contain fourteen additional general content requirements, several of which are broken down into great detail or subparts. ${ }^{36}$ In general, these relate to delineation of responsibilities of the parties, insuring proper accounting, insuring that information is shared freely with the tribe, providing certain financial benefits to the tribe (and clarifying maximum liabilities for certain expenses), clarifying and limiting certain aspects of the relationship, such as ownership, sub-contracting, the grounds and mechanisms for modifying or terminating the contract, and insuring clarity as to when the contract is effective.

a. Legality. The management contract must explicitly provide that all gaming conducted under the management contract will be conducted in accordance with IGRA and the tribal gaming ordinance. ${ }^{37}$

b. Assignment of Responsibilities. The management contract must explicitly assign responsibility for sixteen identified functions to the tribe or the contractor. ${ }^{38}$ The functions include: 1) maintenance and improvements, 2) provision of operating capital, 3) establishment of operating days and hours, 4) employee management, 5) maintenance of books and records, 6) preparation of financial statements and reports, 7) provision of an independent auditor, 8) security personnel management, 9) provision of fire protection services, 10) marketing, 11) payment of bills and expenses, 12) establishment of employment practices, 13) provision of insurance, 14) compliance with Internal Revenue Code, 15) allocation of cost of increased public safety services, and 16) environmental compliance.

With some exceptions, ${ }^{39}$ the NIGC generally does not express any preference as to which party accepts each of these responsibilities. These provisions are designed to force the parties to address issues that might not otherwise be addressed and presumably to give government authorities a clearly responsible target if the public responsibilities of the enterprise, including providing for public safety, are not met. For example, the requirement in item fourteen of assigning who is responsible for compliance with the Internal Revenue Code works, as a practical matter, to assign culpability so as to give the Internal Revenue Service a clear target in the case of illegal tax avoidance or fraud; it prevents one party from using ambiguity in the contract to deny liability by claiming that it was the responsibility of the other party.

c. Accounting. Another important content requirement relates to accounting. Under NIGC regulations, a management contract must explicitly provide for the establishment of satisfactory accounting systems and procedures that include an adequate system of internal accounting controls, permit the preparation of financial statements in accordance with generally-accepted accounting principles, are susceptible to audit, allow the calculation of fees,

\footnotetext{
${ }^{36}$ See 25 C.F.R. § 531.1(a)-(n).

${ }^{37}$ See 25 C.F.R. $\$ 531.1(\mathrm{a})$.

${ }^{38}$ See 25 C.F.R. 531.1(b)(1)-(16).

${ }^{39}$ For example, as to item seven (provision of an independent auditor), the NIGC regulations require the tribe to hire the independent auditor. A management contract may, however, limit the choices the tribe faces, such as designating a "nationally recognized firm."
} 
permit the calculation and payment of a manager's fee, and provide for the allocation of operating expenses or overhead expenses among the tribe, the gaming operation, the contractor, and any other use of shared facilities and services. ${ }^{40}$ These requirements serve many of the same functions as the requirements discussed above by making one party clearly responsible to government authorities. However, they also serve the purpose of insuring that the books are suitable for audit. This provision works handin-glove with the NIGC's annual independent audit requirements ${ }^{41}$ that are imposed on Indian gaming operations; the independent audit requirement makes many of the NIGC financial concerns self-enforcing by requiring the enterprise to satisfy an independent auditor who will produce a report that will be submitted to the NIGC. However, the annual independent audit requirement also creates some complications for management contracts. The NIGC routinely asks the parties to define the gaming operation in the contract in a manner that maintains clarity and appropriate separation in the independent audit and financial reports. For example, some management contracts are for activities in addition to gaming, such as gifts, concessions, restaurants, resorts, hotels, convention and meeting facilities, parking, and other activities. Inclusion of non-gaming activities in the definition of the gaming operation can therefore obfuscate or distort gaming revenue figures in the audit. The NIGC frequently addresses this issue at the initial review stage.

d. Information-sharing and Access. The content requirements also include provisions related to information-sharing and access. First, the contract must explicitly require the management contractor to provide verifiable financial reports, or the information necessary to prepare such reports; to the tribal governing body not less frequently than monthly. ${ }^{42} \mathrm{Sec}^{-}$ ond, the management contract must explicitly require the management contractor to provide immediate access to the gaming operation, including its books and records, by appropriate tribal officials, who shall have the right to verify daily gross revenues and income and access to any gaming related information the tribe deems appropriate. ${ }^{43}$ e. Development \& Construction Costs and Termination. The management contract must provide for a minimum guaranteed monthly payment to the tribe in a sum certain that has priority over the retirement of development and construction costs. ${ }^{44}$ It must also provide an agreed maximum recoupment for development and construction costs. ${ }^{45}$ It must also provide the grounds and mechanisms for modifying or terminating the contract. ${ }^{46}$

f. Dispute Resolution. The content requirements also address dispute resolution. The management contract must contain a mechanism for resolving three kinds of disputes that might arise in relation to the gaming operation: disputes between the manager and the customers, disputes between the manager and the tribe, and disputes between the manager and employees. ${ }^{47}$ While most parties have carefully considered how to resolve disputes between the manager and the tribe, they often have not addressed the other two issues in the contract. The NIGC frequently notes deficiencies for failure to address manager-customer disputes and manager-employee disputes with sufficient clarity on initial submission of a contract.

Another dispute resolution problem that arises often relates to arbitration. The parties frequently select arbitration as the primary means for addressing disputes between the tribe and the manager. However, the NIGC has drawn a firm line as to which disputes are appropriate for arbitration and which are not. While the NIGC is willing to allow parties to arbitrate commercial disputes, the NIGC jealously guards the tribe's governmental authority over the regulation of the Indian gaming enterprise. Thus it routinely rejects arbitration provisions that might be interpreted to give an arbitrator the power to change governmental

\footnotetext{
40 See 25 C.F.R. $\$ \$ 531.1(c)(1)-(5)$.

41 See 25 C.F.R. \$§ 522(b)(3), 522.6(b), 571.12. See also NIGC Bulletin 97-2, Audit Requirements for Gaming Operations, available on the NIGC Web site at 〈http://www.nigc.gov/nigc/documents/bulletins/ NIGC-97-2.jsp $\rangle$.

42 See 25 C.F.R. $\$ 531.1(\mathrm{~d})$.

43 See 25 C.F.R. $\$$ 531.1(e).

44 See 25 C.F.R. $\$ 531.1(f)$.

45 See 25 C.F.R. $\$$ 531.1(g).

46 See 25 C.F.R. $\$ 531.1(\mathrm{j})$.

${ }^{47}$ See 25 C.F.R. $\$ 531.1(\mathrm{k})$.
} 
decisions, such as tribal licensure decisions. The NIGC frequently finds content deficiencies in this area on initial submission of a contract. g. Assignments, Subcontracting, Changes in Ownership, and Effective Date. Under NIGC regulations, the management contract must also indicate whether and to what extent contract assignments and subcontracting are permissible ${ }^{48}$ and whether and to what extent changes in the ownership interest in the management contract require advance approval by the tribe. Because of the need for a background investigation for any person or entity with a substantial ownership interest in the management contracting entity, the parties are, as a practical matter, often seriously constrained as to modifications of ownership. Finally, the management contract must state that the contract shall not be effective unless and until it is approved by the NIGC Chairman. ${ }^{49}$

h. Content Prohibitions. While the previous requirements deal primarily with affirmative content, that is, provisions that each contract must have, NIGC content requirements also have a negative component. The regulations prohibit a management contract from conveying any interest in land or other real property absent specific statutory authority and an explicit statement in the contract. ${ }^{50} \mathrm{It}$ is generally against federal Indian affairs policy to allow further deterioration of the Indian land base. As a result, Indian tribes have long been required to seek federal approval to convey trust land to outsiders. ${ }^{51}$ The purpose of this provision is thus to prevent land from being conveyed from the Indian tribe to an outside party as part of the compensation for the management of a casino under the apparent approval of the federal government.

\section{Background investigations}

Among the most important purposes of gaming regulation in all jurisdictions is to protect this cash-intensive industry from criminal activities. The NIGC's specific mandate is to shield the Indian gaming industry from organized crime and other corrupting influences. ${ }^{52}$ The general purpose of the background investigation is to determine whether a person or entity involved in gaming poses a threat to the in- tegrity of the gaming industry. Because NIGC does not use a licensure process, NIGC review is somewhat different than the process in other jurisdictions.

When the NIGC begins review of the contract terms, NIGC staff will usually perform some level of background investigation. The background investigation requirements are different for Class II and Class III gaming and, perhaps ironically, are more extensive for Class II gaming (bingo and related games) than Class III gaming (all other commercial gaming, such as slot machines, blackjack, and roulette). ${ }^{53}$ For management contracts providing for both Class II and Class III gaming, the NIGC must use the more extensive Class II procedures. This likely causes some contractors to limit the management contract to Class III gaming. The requirements are set forth below.

For management contracts involving Class II gaming, the NIGC must conduct a background investigation of the following persons: each person or entity that is a party to a management contract and each person who has management responsibility for the management contract, each person who is a director of a corporation that is a party to the management contract, the ten persons who have the greatest financial interest in a management contract, any business entity with a financial interest in the contract, and any other person with a financial interest whom the Chairman wishes to investigate. ${ }^{54}$ As noted, for business entities owned by numerous shareholders, the NIGC routinely limits background investigations to the ten

48 See 25 C.F.R. $\$$ 531.1(1).

49 See 25 C.F.R. \$ 531.1(n).

50 See 25 C.F.R. $\$ 531.2$

51 See, e.g., 25 U.S.C. § 81.

52 See Section 3 of the Indian Gaming Regulatory Act, 25 U.S.C. $\$ 2702$.

53 Though, at first glance, it is surprising that the NIGC has a greater responsibility for background investigations of Class II gaming (bingo and similar games) management contracts than for Class III gaming (such as slot machines and house banked games) management contracts, the apparent justification was that state governments would provide for such investigations in the gaming compacts which are required for Class III gaming. Few states have used the compact process to establish a role in tribal gaming background investigations.

${ }^{54}$ See 25 C.F.R. $\$ \S 533.6($ b) , 537.1. 
largest shareholders. ${ }^{55}$ The management contractor must facilitate this investigation by providing extensive information on the individuals subject to investigation and by financing the investigation through a fee paid (or guaranteed through a letter of credit) to the NIGC at the time the contract is submitted to the NIGC for review. ${ }^{56}$

The Chairman must disapprove any Class II management contract if the persons with a direct or indirect financial interest is 1 ) an elected member of the governing body of the tribe that is a party to the management contract, ${ }^{57} 2$ ) has been convicted of a felony or a misdemeanor gaming offense, ${ }^{58} 3$ ) has knowingly and willfully provided false information to the NIGC or a tribe, ${ }^{59} 4$ ) has refused to answer questions for the NIGC background investigation, ${ }^{60}$ or 5) is determined to be a person "whose prior activities, criminal record, if any, or reputation, habits, and associations pose a threat to the public interest or to the effective regulation and control of gaming, or create or enhance the dangers of unsuitable, unfair, or illegal practices, methods, and activities in the conduct of gaming or the carrying on of related business and financial arrangements." 61

As to Class III gaming, the standard is less strict. The Chairman may (rather than shall) disapprove a management contract if he finds that a person in the fifth category above has a financial interest or management responsibility related to a management contract. ${ }^{62}$ However, the Chairman is somewhat less likely to make such a determination because, in contrast to the extensive background information required for persons involved with Class II management contracts, the principals in a Class III management contract are only required to provide basic information related to identity. ${ }^{63}$

As a practical matter, the NIGC background investigation uses the same methods as investigations in other jurisdictions. Background investigators will review criminal and arrest records and files, determinations from other gaming jurisdictions, financial records, records of court disputes, and any other substantive and reliable information that the background investigations can unearth.

In the gaming industry generally and at the NIGC, this type of review is often called a "suit- ability determination."64 However, in the Indian gaming industry, this label is somewhat misleading. Unlike in most regulatory jurisdictions in the commercial gaming industry in which the purpose of the investigation is licensure, a successful background investigation will not result in a formal finding by the NIGC Chairman. Although the unsuitability of an applicant for any of a variety of reasons, such as a prior criminal record, untruthfulness, or uncooperativeness, is a basis for disapproval of the management contract, no formal finding is made for an approval. ${ }^{65}$ Approval of a management contract, at least if it is for Class II gaming, therefore constitutes an implicit finding of suitability.

Although the background investigation is a tedious process, many persons subject to NIGC background investigations are licensed in other jurisdictions. The NIGC has memoranda of understanding with numerous state and tribal gaming jurisdictions which allow the sharing of background information on persons and entities. In light of the cooperation between the NIGC and other jurisdictions and the limited investigative resources of the NIGC, an individual who has successfully completed a full background investigation in another gaming jurisdiction has a favorable chance of obtaining NIGC approval. As a practical matter, the NIGC generally does not seek to impose standards on the Indian gaming industry that are more stringent than the standards that exist in other legitimate gaming jurisdictions and, accordingly, it is unlikely to reach a decision different than other regulatory agencies. Accordingly, if the persons and entities subject to a NIGC background investigation have successfully completed a background investigation in

55 See 25 C.F.R. $\$ 537.1(\mathrm{c})$.

56 See 25 C.F.R. $\$ 537.3$.

57 See 25 C.F.R. $\$ 533.6(\mathrm{~b})(1)(\mathrm{i})$.

58 See 25 C.F.R. $\$ 533.6(\mathrm{~b})(1)(\mathrm{ii})$.

59 See 25 C.F.R. \& $533.6(\mathrm{~b})(1)$ (iii).

60 See 25 C.F.R. $\$ 533.6($ b)(1)(iv).

6125 C.F.R. \& 533.6(b)(1)(v).

62 See 25 C.F.R. $\$ 533.6(\mathrm{c})$.

${ }^{63}$ See 25 C.F.R. $\$ \S 533.3(\mathrm{~d}), 537.1(\mathrm{~b})$.

${ }^{64}$ See NIGC Bulletin 94-2-Suitability Determinations (April 20,1994) (available on the NIGC Web site).

65 See 25 C.F.R. $\$ \S 533.6($ b) $)$ 537.4. 
another gaming jurisdiction (a fact that the NIGC specifically requests be disclosed), ${ }^{66}$ it would be unusual for the Chairman to disapprove a management contract on the basis of an unsatisfactory background investigation, unless circumstances have changed since the previous background investigation.

As a practical matter, if a person subject to the background investigation requirements becomes a cause for concern to the NIGC staff, NIGC staff will encourage the parties to restructure the membership of the management contractor to terminate the participation of the person for whom there is concern. The NIGC has worked with parties to remove an individual from the management contract when the person was thought to be unsuitable for participation in a management contract but has approved the contract after removal of the unsuitable person. Thus, it is unusual for a background investigation to become a basis for disapproval of a management contract.

\section{Environmental review}

The third significant area of NIGC activity prior to a management contract approval is environmental review in accordance with the $\mathrm{Na}$ tional Environmental Policy Act (NEPA), ${ }^{67}$ and in rarer cases, the Endangered Species Act (ESA), ${ }^{68}$ and related statutes. ${ }^{69}$ Under NEPA, federal agencies must identify and consider in their decision-making processes the environmental impact of any agency action significantly affecting the quality of human environment. $^{70}$ The NIGC has, at least informally, interpreted its responsibility under NEPA to require the parties to submit an environmental assessment of any management contract under review that involves major construction of a casino. ${ }^{71}$

Under NEPA, after reviewing an environmental assessment, a federal agency must find either that the project has no significant environmental impacts or, if there are such impacts, order the parties to prepare an environmental impact statement (EIS) to catalogue those impacts. In most cases, a middle route is taken in which the agency identifies mitigation measures that will insure that there are no significant impacts. However, if there are such im- pacts and the parties are then required to prepare an EIS, the NIGC Chairman must consider the EIS in his decision as to whether to approve the contract.

Under the ESA, a federal agency must engage in "section 7 consultation" with the Fish and Wildlife Service (FWS) or the National Marine Fisheries Service (NMFS) before proceeding with any action that "may affect" any species listed under the ESA. ${ }^{72}$ Informal consultation may be adequate if the action is not likely to have any adverse affect. Formal consultation, including a biological assessment by the action agency (NIGC) and a biological opinion from the consulting agency (FWS or NMFS) will be required if the action is likely to have an adverse effect. ${ }^{73}$

The NIGC has never disapproved a management contact because of significant impacts on the environment. Indeed, the NIGC has never even determined that a casino construction project caused significant environmental impacts requiring the preparation of an environmental impact statement. Because commercial (non-Indian) gaming establishments are not subject to federal approval and therefore need not comply with the NEPA process, NEPA places Indian gaming establishments at a competitive disadvantage as compared with commercial gaming establishments. The NIGC seems to have been sensitive to this concern and has applied NEPA in a manner that would

\footnotetext{
${ }^{66}$ See 25 C.F.R. \$ 537(b)(1)(viii).

6742 U.S.C. $\$ 4321-4370(d)$.

6816 U.S.C. $\$ 1536$.

${ }^{69}$ Other statutes may apply, depending on the project. For example, a Clean Water Act Section 404 permit may be necessary if the construction involves discharge of dredge and fill materials into waters of the United States. See 33 U.S.C. $\$ 1344$. State environmental statutes may also apply. Most of these statutes, though they may bind the parties, do not directly affect the NIGC decision-making process and thus are not considered here. They may however significantly affect how parties address issues related to the NIGC's environmental review.

${ }^{70}$ See generally 42 U.S.C. $\$ 4332$ (C).

71 If construction would not occur "but for" the gaming management contract, the NIGC routinely determines that the gaming management contract review process implicates NEPA and an approval decision may only be issued after environmental review.

72 See generally 16 U.S.C. $\$ 1536$.

73 See generally 50 C.F.R. Part 402.
} 
minimize its anti-competitive effects. While an EIS may theoretically be required in some circumstances, NEPA does not require disapproval but merely a full statement of significant impacts before an approval. Accordingly, while the onerous task of preparing an environmental impact statement might slow the process of a management contract, it would be unlikely to result in a disapproval of a management contract.

The NIGC routinely requires environmental assessment of the construction plans and often requires the parties to take sufficient mitigation measures to minimize any such impacts. However, the NIGC has simply never disapproved a gaming management contract based on the casino project's likely impact on the environment. ${ }^{74}$ In each case to date in which the NIGC Chairman has approved a management contract in which NEPA applied, the Chairman has ultimately issued a "finding of no significant impact" (FONSI) following the environmental analysis and prior to contract approval. Parties have regularly been willing to modify construction plans to mitigate those impacts. In recent years, the Department of Justice has indicated less willingness to defend the NIGC when it conducts environmental assessments and issues FONSIs; the NIGC may therefore be required to insist on an EIS in close cases. On several recent occasions, tribes have been more cautious and have opted to draft an EIS. Because of litigation risk in failing to proceed on this route, parties may be well advised to err on the side of caution in planning the management contract approval process to avoid litigation that will further slow approval.

\section{THE ROLE OF COLLATERAL AGREEMENTS IN NIGC MANAGEMENT CONTRACT REVIEW}

A contract for the management of a gaming operation is often only one component of a complex relationship between an Indian tribe and an outside entity. The parties may have also reached numerous agreements for construction and development of the gaming facility and/or other facilities, for financing, for the purchase of land, and for all sorts of other purposes. It is facile to suggest that these other agreements are entirely unrelated to the management contract, however, because the gaming is usually the heart of the entire development.

The NIGC strictly has jurisdiction to review and approve only "management contracts." A management contract that has not been approved by the NIGC is void. ${ }^{75}$ The NIGC regulations define management contract as "any contract, subcontract, or collateral agreement between an Indian tribe and a contractor . . . if such contract or agreement provides for the management of all or part of the gaming operation." ${ }^{176}$ A collateral agreement, in turn, is defined as "any contract, whether or not in writing, that is related, either directly or indirectly, to a management contract, or to any rights, duties or obligations created between the tribe (or any of its members, entities, or organizations) and a management contractor or subcontractor (or any person related to a management contractor or subcontractor). ${ }^{\prime 77}$ In other words, a "collateral agreement" is a contract that is either related to a management contract or is between the same or similar parties. Thus, the hypothesized development and construction agreement, the financing agreement(s), and the land purchase agreement are often considered "collateral agreements" either because they are related to the management agreement and/or

${ }^{74}$ For example, in 2002, the NIGC issued a finding of no significant impact and ultimately approved a gaming management contract between the Twenty Nine Palms Band of Mission Indians and a gaming management entity including Donald Trump for an Indian casino located at the edge of the Joshua Tree National Park in Southern California. The environmental compliance issues were particularly sensitive in that case in light of the facility's proximity to an important and remote National Park with a delicate desert ecosystem. Nevertheless, the environmental compliance was completed and the management contract was approved by the NIGC, all in two years from the time the contract was originally submitted to NIGC for approval. See Benjamin Spillman, Trump Visits Spotlight 29 Casino, The (Palm Springs) Desert Sun, January 30,2002 (noting that the agreement was first announced in March of 2000 and presumably was submitted to the NIGC at that time). The NIGC approved the management contract on April 15, 2002. See NIGC List of Approved Management Contracts, on the NIGC Web site.

75 See 25 C.F.R. $\$ 533.7$.

7625 C.F.R. $\$ 502.15$.

7725 C.F.R. $\$ 502.5$. 
because they are between the same or similar parties.

Perhaps because of the perceived circularity of the definition, courts have shown some confusion as to the treatment of collateral agreements and have occasionally presumed that each document meeting the definition of collateral agreement is subject to approval by the NIGC. ${ }^{8}$ This approach is incorrect. As a practical matter, the NIGC does not take this view (and has not been a party to the decisions that have discussed the NIGC approval requirements). The NIGC does not approve each document that meets the definition of collateral agreement. Indeed, it has no standards to use for approval of such documents. The NIGC routinely approves management contracts while failing to approve documents collateral to that management contract. It does not intend that such agreements are void; it simply means that the NIGC seeks to approve only that document that actually involves management of a gaming operation. The NIGC has authority to approve a collateral agreement only if it also meets the definition of "management contract," that is, it provides for the "management of all or part of a gaming operation." In short, not all collateral agreements are management agreements. Those that do not meet the definition of "management contract" are not subject to NIGC review.

That is not to say that the NIGC does not seek to review all collateral agreements. There are several reasons why it seeks to review such documents. First, the NIGC must make its own determination as to whether the collateral agreement is also a management contract. Since a management contract is void absent NIGC approval, it is prudent to allow the NIGC to undertake such review. These contracts under review, referred to internally at NIGC as "R contracts," are often found by the NIGC not to be management contracts. Upon request, the NIGC will review a contract and issue a letter indicating that the contract is not subject to the management contract review and approval process.

Second, the NIGC must look at collateral agreements as part of its review of the management contract. The NIGC must obtain a full and complete disclosure of the financial rela- tionship between the tribe and the contractor or related entities to insure that the parties have not sought to evade the compensation limits set forth in IGRA. Most management contractors are paid not a fixed fee, but a percentage of gaming revenues. One concern is that parties might seek to evade those limits by hiding additional terms of compensation for management in other agreements that receive far less NIGC scrutiny. To determine whether the parties have exceeded IGRA's compensation limits, NIGC staff must have a clear understanding of the entirety of the financial relationship between the parties and thus a full comprehension of the compensation to the management contractor.

Although a tribe may lawfully compensate the management contractor for rendering services other than gaming management, the NIGC will scrutinize all collateral agreements, such as loan and financing agreements, development agreements, hotel and retail operation agreements, land purchase agreements, to insure that the compensation terms in those contracts are fair for the services rendered and that those agreements thus are not intended to allow the parties to evade the compensation limit of thirty percent of net gaming revenues. The NIGC will scrutinize these other contracts to insure that the fees are adequately supported by valuable consideration.

Consider, for example, a loan agreement that contains terms that are substantially higher than current market rates. While parties might seek to justify such terms by arguing that such investments are risky, the Indian gaming industry has developed a sufficient track record that financing has become much less expensive for tribal casinos. Thus, a financing arrangement involving the same or similar parties in the management agreement that provides an independent source of economic advantage might appear suspicious under close NIGC scrutiny. If other financing is available elsewhere at substantially lower rates, the NIGC may withhold approval of the management

${ }^{78}$ See, e.g., Catskills Development v. Park Place Entertainment, 144 F.Supp.2d 215 (S.D.N.Y. 2001), 154 F.Supp.2d 696 (S.D.N.Y. 2001), 217 F.Supp.2d 423 (S.D.N.Y. 2002). 
contract until it is satisfied that the financing agreement is not an attempt to evade IGRA compensation standards. In other words, the NIGC's management contract approval authority may be used by NIGC staff to require the parties to lower the financing costs, even if the financing agreement is technically a collateral agreement that does not rise to a management agreement.

The NIGC tends to be uncomfortable with ancillary contracts that provide for additional percentage participation in the gaming revenues. If, for example, a management contractor is earning a management fee between 30 and 40 percent of gaming revenues and seeks an additional percentage of gaming revenues for non-management services, such as financing or development fees, the NIGC may be concerned that the manager/financer/lenders' share of the gaming revenues may leave the tribe with a very small portion, rendering the operation unprofitable for the tribe. Thus, the NIGC generally prefers that other services be provided on the basis of a fixed or hourly fee. It cannot insist on such terms when the financer or developer is an entirely unrelated entity not engaging in management because it lacks authority over such parties. Where the development or financing contract meets the definition of collateral agreement because the parties are related, however, the NIGC can be more insistent.

In summary, the NIGC created a broad definition of the term "collateral agreement" to insure that it can review all the documents needed for meaningful management contract review. Thus, review of collateral agreements is a key ancillary aspect of management contrast review. 